\title{
KOMODIFIKASI: CERMIN RETAK AGAMA DI TELEVISI: PERSPEKTIF EKONOMI POLITIK MEDIA
}

\author{
Muhamad Fahrudin Yusuf \\ Dosen Jurusan Komunikasi dan Penyiaran Islam IAIN Salatiga \\ mfakhrys@gmail.com
}

\begin{abstract}
Co-modification of religion has been penetrating on commercial television in Indonesia for long time. The program produced by Indosiar "Mamah dan Aa Beraksi", "Islam itu Indah" launched by Trans TV, a soap opera entitled "Tukang Bubur Naik Haji" played on RCTI, an Indian serial film entitled "Jodha Akbar" and imported Turkish Film "Abad Kejayaan" played on ANTV, and similar drama entitled "Cermin Kehidupan" played on Trans 7 are some examples of the programs. Based on the observation and writer's thought, it was found that the preacher, contents of program, even the audiences include the religion into the program and it was interrupted with capitalism. In the other hand, Religion should be avoided from this case.
\end{abstract}

Keyword: Comodification, Religion, Television.

\begin{abstract}
Abstrak
Komodifikasi agama telah lama merambah di televisi komersial di Indonesia. Dari program "Mamah dan Aa Beraksi" Di Indosiar dan "Islam Itu Indah" di Trans TV hingga sinetron "Tukang Bubur Naik Haji" (TBNH) di RCTI, film seri India "Jodha Akbar" dan drama seri impor Turki "Abad Kejayaan" di ANTV dan acara serupa seperi sinetron "Cermin Kehidupan" di Trans 7. Melalui pengamatan sekilas dan studi pemikiran penulis didapati temuan bahwa dai, konten hingga audiens agama yang semestinya berada di luar area kontestasi.tak luput dari kepentingan kapital itu.
\end{abstract}

Kata Kunci: Co-modification, Agama, Televisi . 


\section{Pendahuluan}

Isi media tidak lain adalah cermin realitas sosial. Cermin yang retak tidak akan dapat memberikan informasi yang utuh. Begitu pula yang diduga terjadi pada informasi keagamaan di televisi komersial.

Jagat televisi komersial di Indonesia, Islam digambarkan sebagai fakta yang unik. Agama digambarkan sebagai jalan terbaik untuk mencapai kebahagiaan dunia dan kehidupan berikutnya melalui ceramah keagamaan. Agama juga dapat berwujud sebagai sesuatu yang membuat geram atau bahkan menyeramkan. Bayangan geram atau takut itu akan muncul manakala disebut kata Haji Muhidin, teroris, radikalisme, tahayul, bid'ah, khurafat, dan sebutan ekstrim lainnya.

Pada satu sisi kemunculan Islam dengan kebaikannya di media membawa angin segar bagi pemeluknya. Siaran dakwah tentu menggembirakan bagi orang yang mempunyai perhatian khusus pada agama Islam, baik akademisi, pemuka agama, maupun pengamat sosial keagamaan, dan tentunya pemeluknya. Pada sisi lain tampilnya wajah buruk agama melalui isu radikalisme, teror, citra buruk karakter seorang tokoh seperti Haji Muhidin atau bahkan tampilan da'i yang tidak kompeten menjadi kado pahit bagi pemeluknya. Tulisan ini mencoba untuk menguak sisi buruk media televisi komersial dalam menyiarkan program keagamaan di televisi nasional Indonesia.

Media tidak hidup di ruang hampa, media hidup di dalam suatu sistem sosial dalam suatu masyarakat. Kondisi media di Indonesia pasca orde baru, media penyiaran digambarkan, hidup di dalam sistem yang cenderung market-based-power. Gejala ini antara lain bisa dilihat pada kecenderungan terjadinya komodifikasi agama di media. Meski nampak kabur, bagi media komersial, agama adalah budaya massa. Sebagai salah satu unsur budaya agama layak dikonversi menjadi komoditas yang menguntungkan. 
Informasi dan hiburan bernuansa agama adalah preferensi realistis bagi khalayak yang religius seperti halnya masyarakat Indonesia. Tidak hanya program dakwah seperti Mamah dan Aa Beraksi di Indosiar dan Islam Itu Indah di TransTV mendapat simpati pemirsa. Ekspansi atas nama agama juga nampak marak dengan hadirnya sinetron bernuansa agama seperti Tukang Bubur Naik Haji (TBNH) di RCTI, film seri India Jodha Akbar dan drama seri impor Turki Abad Kejayaan di ANTV dan acara serupa seperi sinetron Cermin Kehidupan di Trans7.

Realitanya sebuah program agama ditayangkan di televisi komersial bukan hanya lantaran disukai pemirsa. Sebuah temuan menyebutkan terjadinya komodifikasi dalam beberapa aspek pada ceramah Ustadz Nur Maulana dalam program Islam Itu Indah di TransTV. Melalui analisis McDonalisasi; efisiensi, kalkulabilitas, prediktabilitas, dan kontrol melalui teknologi nonmanusia, didapati kombinasi komodifikasi pada isi dan audiens program tersebut (http://nouriesblog.blogspot.com/). Meskipun penelitian ini gagal mengungkap sisi instrinsik dan ekstensifitas dari komodifikasi dalam acara yang bersangkutan.

Kegemaran sebagian masyarakat pada sinetron semakin tidak terbendung, sehingga sinetron bernuansa Islam seperti Tukang Bubur Naik Haji (TBNH) di RCTI selalu menempati rating tertinggi, bergantian dengan Jodha Akbar di ANTV yang sama-sama mengusung simbol Islam. Begitu juga dengan Abad Kejayaan di ANTV (https://id-id.facebook. com/RatingAcaraTelevisiIndonesia).

Masyarakat Indonesia sebagai audiens tentu tidak sepenuhnya menyadari akan efek buruk yang ditimbulkan oleh hiburan yang mereka pilih. Mereka masih belum sepenuhnya menyadari bahwa apa yang ada dan terjadi di televisi adalah realitas yang dikonstruksi. Artinya gerakan literasi (melek) media belum sepenuhnya menyentuh seluruh lapisan masyarakat awam media. Mereka umumnya masih menganggap televisi sebagai sumber utama informasi, hatta ilmu agama. 
Akibatnya mereka lebih memilih menikmati pengajian dari televisi tanpa meninggalkan tempat duduk nyaman di dalam rumah mereka, dibanding mengaji kepada Kyai, Ustadz atau Guru Ngaji lokal yang umumnya secara keilmuan lebih mendalam, bahkan tidak sedikit dari mereka adalah akademisi di perguruan tinggi keagamaan.

Keluguan audiens inilah yang akhirnya dimanfaatkan oleh televisi komersial dengan menggelontorkan program-program religius yang menurut media audio visual itu digemari khalayak. Dapat diduga komoditas baru atas nama agama semakin banyak menghiasi layar kaca pemirsa setia televisi. Pada akhirnya preferensi atas acara televisi kegemaran itu dikonversi menjadi rating dan dijual kepada pengiklan. Audiens yang sejatinya adalah pemilik sah frekuensi sekali lagi menjadi korban kekuatan kapitalisme media.

Persoalan yang muncul kemudian adalah bagaimanakah komodifikasi yang terjadi di televisi komersial di Indonesia? Mengapa isu keIslaman, baik itu siaran dakwah atau siaran hiburan masih layak tayang di televisi komersial?

\section{Televisi, Budaya dan Televisi Komersial}

Media merupakan alat atau sarana yang digunakan untuk menyampaikan pesan dari komunikator kepada khalayak (Cangara, 2007:123). Pengertian ini memang secara hanya memberi deskripsi bahwa media hanyalah sebagai sarana penyampaian pesan. Namun demikian sudah cukup untuk menjawab pertanyaan etimologis tentang media.

Menurut Onong Uchyana Effendi (2003:7) media massa terdiri dari surat kabar yang mempunyai sirkulasi luas, siaran radio dan televisi yang ditujukan untuk umum, dan film yang dipertunjukkan di gedunggedung bioskop. Media massa lebih merujuk kepada khalayak yang secara geografis tidak diketahui keberadaannya (Cangara, 2007:126). Artinya khalayak media massa heterogen dan secara geografis berjauhan 
dan tidak saling mengenal dan dapat menyentuh seluruh masyarakat dari berbagai umur dan kelas sosial.

Kelebihan media ini disamping mampu menyiarkan informasi dalam bentuk audio visual secara langsung maupun tunda, coverage (daya jangkau) yang luas dan sifat one to many yang dimilikinya, kelebihan yang tidak dimiliki oleh media lainnya seperti surat, pamflet, telefon dan lain sebagainya, bahkan oleh media massa lain seperti halnya koran dan buku serta film. Televisi merupakan salah satu media yang disepakati ilmuwan komunikasi mampu menyampaikan pesan secara masif. Kemampuannya untuk mengirim pesan yang terdiri dari gambar dan suara ke seluruh belahan dunia menjadikannya memiliki tempat tersendiri dihati khalayak media. Waktu luang bagi mereka merupakan waktu untuk menonton televisi.

Pernyataan di atas dibuktikan dengan beberapa penelitian yang dilakukan pada masyarakat Amerika bahwa hampir setiap orang di benua itu menghabiskan waktunya antara 6-7 jam per minggu untuk menonton TV (Cangara, 2007:145). Salah satunya adalah penelitian yang dikutip Samovar dkk (2010:42) pada tahun 2007 di AS. Hasil temuannya adalah bahwa lebih dari 3 jam waktu masyarakat digunakan untuk menonton TV.

Fenomena seperti yang terjadi di Amerika sepertinya tidak terlalu jauh dengan yang terjadi di Indonesia. Munculnya media baru bentukan teknologi komunikasi dan internet tidak serta merta menghilangkan "ritual" menonton TV masyarakat negeri ini. Bahkan bagi orang Indonesia menggunakan dua media sekaligus bisa dilakukan. Misalnya menonton TV sambil SMSan, chatting atau bahkan dapat dilakukan secara bersamaan dengan tanpa memalingkan wajah sedikitpun dari kotak ajaib tersebut.

Konsep budaya menurut Herskovits (dikutip Gudykunst 2002:26) adalah segala sesuatu yang dibuat manusia. Pernyataan Herkovits mungkin masih terlalu umum dan mencakup seluruh lini kehidupan. Secara tegas Hall (dikutip Gudykunst 2002:26) menyamakan budaya dengan komunikasi: "Budaya adalah komunikasi dan komunikasi adalah 
budaya". Definisi ini tidak berlebihan, budaya tanpa komunikasi dengan bahasa dan simbol lainnya, tidak akan pernah ada.

Meskipun demikian kedua konsep budaya yang diajukan oleh dua pakar budaya itu menunjukkan betapa hubungan budaya dan komunikasi, dalam hal ini komunikasi massa, sangatlah erat. Bahkan pakar kedua menyamakan kedua konsep yang secara definitif berbeda. Tidak berlebihan pula bahwa televisi sebagai media komunikasi sudah menjadi budaya di Indonesia. Secara kasat mata dapat dilihat bahwa hampir tidak ada rumah yang tidak ada televisinya.

Menurut Samovar dan kawan-kawan (2010:32) budaya harus dipelajari. Salah satu saluran untuk mempelajarinya adalah melalui media massa, atau dalam hal ini adalah TV. Lanjut Samovar dan kawan-kawan dengan mengutip Thompson, bahwa hanya sedikit orang yang menyangkal bahwa pengalaman budaya modern sangat besar dipengaruhi oleh perkembangan komunikasi massa. Media lebih dari sekedar menginformasikan dan menghibur khalayaknya. Namun media juga menyediakan pelajaran tentang budaya dan kesadaran identitas yang terus-menerus dinegosiasikan.

Pernyataan Thompson itu rasanya tidaklah berlebihan. Masyarakat modern adalah masyarakat yang sadar akan pentingnya informasi, termasuk informasi keagamaan, Sehingga ukuran yang dipakai dalam sebagian sisi kehidupannya adalah berdasarkan informasi yang datang dari luar, khususnya media. Televisi masih menjadi produsen informasi handal sampai saat ini. Di Indonesia stasiun televisi dominan adalah stasiun televisi swasta. Televisi swasta di Indonesia dapat dikategorikan ke dalam televisi komersial, sebab menurut Denis McQuail (1994:12) sistem kerja komersial adalah mencari keuntungan dan ketergantungannya yang luarbiasa pada advertensi atau periklanan.

Ciri yang disampaikan McQuail tentu saja tampak pada media televisi swasta di Indonesia. Banyak iklan berlalu-lalang di layar kaca 
pemirsa televisi swasta di Indonesia. Sebut saja Trans TV, Trans7 yang tergabung dalam Trans Corporation. Grup Media Nusantara Citra membawahi RCTI, Inews, Global dan MNC TV. TV ONE dan ANTEVE di bawah Bakrie Group. Global TV, Metro TV, Kompas TV, Rajawali Televisi, SCTV dan Indosiar di bawah Emtex Grup.

Banyaknya stasiun televisi di Indonesia mau tidak mau menyebabkan persaingan sengit antarmedia televisi, stasiun televisi manakah yang akan memenangkan persaingan merebut pangsa khalayak terbanyak salah satunya tergantung pada konten atau program yang disiarkannya dan komodifikasi melalui siaran agama adalah salah satu cara bagi sebuah institusi media untuk bertahan hidup dalam persaingan antarmedia.

\section{Komodifikasi: Pintu Masuk Ekonomi Politik Media}

Komodifikasi adalah salah satu pintu masuk dalam diskursus ekonomi politik media. Dua lainnya adalah spasialisasi dan strukturasi. Sesuai dengan tema tulisan ini, penulis hanya akan membahas secara konseptual dan praktis tentang komodifikasi yang terjadi di televisi komersial di Indonesia.

Kata komodifikasi mungkin belum akrab di telinga sebagian orang, namun bila disebut kata komoditas akan lebih banyak orang menganggukkan kepala tanda mengerti dibanding yang tidak tahu. Kedua kata itu memang memiliki hubungan yang amat erat bila komoditas adalah benda yang dapat dijual untuk mendatangkan keuntungan, maka komodifikasi adalah proses menjadikan benda atau jasa menjadi suatu komoditas.

Vincent Mosco (1996:57) menyebut komodifikasi sebagai: the process of transforming use values into exchange values atau proses mengubah nilai guna menjadi nilai tukar. Sebagai ilustrasi sederhana dapat dideskripsikan bahwa isu keislaman baik dakwah atau lainnya diproduksi menjadi program yang dijual kepada pengiklan. Seperti diketahui iklan merupakan jantung televisi komersial dan media provit lainnya, sehingga dapat 
INJECT: Interdisciplinary Journal of Communication, Vol.1, No.1, Juni 2016: h. 25-42

dikatakan tanpa pengiklan media komersial tidak akan pernah hidup.

Nilai guna di dalam domain komunikasi massa sepertu halnya televisi adalah fungsi atau tujuan dari komunikasi, baik itu dakwah atau program lainnya. Menurut al-Quran misalnya pada surat an-Nisa ayat 138-139, surat al-Fath ayat 28, dan surat al-Hajj ayat 41 , bahwa tujuan komunikasi atau dakwah adalah memberi penjelasan, petunjuk, wejangan tentang Islam secara utuh dan untuk tujuan amar makruf nahi munkar. Sedang fungsi komunikasi pada umumnya adalah to inform, to educate, dan to entertaint. Severin dan Tankard (2009:165) menambahkan fungsi media massa dengan: surveillance, correlation, entertainment dan transmission of the social herritage.

Secara umum hampir tidak ada perbedaan prinsipil antara dakwah melalui media dengan fungsi komunikasi pada umumnya, khususnya pada unsur informasi, pendidikan dipadu dengan sedikit sentuhan hiburan, dan tentunya fungsi persuasi menjadi menonjol dalam siaran agama atau dakwah.

Sementara ekonomi politik sendiri memiliki beberapa pengertian, diantaranya menurut A Dictionary of Political Economy, yang pertamakali di publikasikan di Moskow pada tahun 1981 adalah: science which studies the social relations that evolve between people in the process of the production, distribution, exchange and consumption of material benefits.

Denis McQuail (2005) menyebut ekonomi politik sebagai; The original word for theoretical, but for some time used to critical theorists working in the neo-Marxist tradition to refer to a general view of media and society in which material (economic) factors play a determining role and in which politics is primarily about economic power.

Vincent Mosco (1996: ) secara sempit mendefinisikan ekonomi politik dengan: The study of the social relations, particularly the power relations, that mutually constitute the production, distribution, and consumption of resources, including communication resources 
Mosco melanjutkan definisinya tentang ekonomi politik secara lebih luas dengan "The study of control and survival in social life". Pada intinya ekonomi politik adalah studi tentang bagaimana media dapat bertahan hidup di tengah persaingan antarmedia yang dewasa ini semakin ketat. Mosco menjelaskan bahwa studi tentang ekonomi politik media lahir bersamaan dengan lahirnya moda produk kapitalis, sehingga McQuail (2005) menyebut bahwa studi tentang ekonomi politik produk marxisme baru atau neo-marxian yang secara kritis keduanya memandang bahwa media adalah suprastruktur dari ideologi kapitalisme, dengan demikian ekonomi politik media merupakan bagian dari perspektif kritis dalam studi komunikasi.

Akhirnya pandangan kaum kiri siaran keagamaan di televisi komersial tidak lebih dari kamuflase kaum kapitalis untuk mencari keuntungan ekonomi sebanyak-banyaknya. Bentuk komodifikasi media menurut Mosco (1996) ada empat bentuk komodifikasi di media, yaitu: komodifikasi isi media, komodifikasi audiens, komodifikasi cybernetik (intrinsik), dan komodifikasi cybernetik (ekstensif)

\section{Isi dan Pesan Media Sebagai Komoditas Televisi Komersial.}

Sebuah pesan pada hakikatnya selalu dipengaruhi oleh sistem media di mana pesan itu diproduksi. Di Indonesia pasca runtuhnya orde baru media mendapati momen perubahan. Bila di masa orde baru televisi lebih berfungsi sebagai corong pemerintah dalam arti hanya mengabdi kepada penguasa, maka di era berikutnya pasar menjadi acuan media berikutnya (market based power). Ideologi atau isi media yang muncul bagi pemikir ekonomi politik media juga cenderung mengikuti kepentingan kapitalis. Termasuk siaran agama dan isu-isu keagamaan.

Onong Uchyana Effendi (2001) menyebut bahwa isi atau content media terdiri dari bahasa dan simbol (lambang). Fenomena yang terjadi di televisi komersial materi agama yang disiarkan, disimbolkan dengan 
bahasa dimana program itu diproduksi, yaitu, bahasa Indonesia. Bukan bahasa Arab yang dikenal sebagai bahasa "islami”. Simbol agama juga nampak dengan dai atau daiyah, kopiah, peci, jilbab, wardrobe dan aksesoris lainnya. Simbolisasi agama ini menjadi hal penting dalam proses komodifikasi, parameter ekonomi jelas menjadi ukuran dalam kebijakan pemilihan simbol dan bahasa.

Dalam praktiknya pesan agama diproduksi dengan bahasa yang mudah dimengerti oleh khalayak dalam upayanya menarik pasar pengiklan. Isu-isu rumah tangga seperti problem-problem kekeluargaaan, problem mendidik anak dan persoalan sehari-hari dipandang sebagai pesan yang dapat diterima pasar, sebab mudah dicerna oleh khalayak umum. Isu-isu politik, hukum dari perspektif agama juga tidak terlalu nampak. Dalam hal ini terjadi pengebirian materi agama. Padahal Islam adalah kaffah, mengatur segala lini kehidupan.

Pesan yang dihasilkan cenderung monoton, terasa kurang bermutu dan bermakna. Hingga ajaran agama terpuruk dan terjabak dalam budaya massa, dalam istilah Dennis McQuail disebut dengan program berselera rendah, low taste. Unsur hiburan juga nampak lebih menonjol daripada nilai-nilai agama. Padahal pesan agama haruslah disampaikan oleh mereka yang berkompeten. Bukan mereka yang menarik dan dibesarkan bagi dan oleh media.

Sementara Komunikator atau da'i yang tampil di televisi bukanlah pilihan langsung pemirsa. Kebijakan manajemen dari stasiun terkait mengharuskan da'i pengisi adalah mereka yang diterima oleh pasar dan menguntungkan secara ekonomi, sehingga bukan nama besar yang lahir dari masyarakat, namun nama yang dibesarkan oleh media.

Pada saat ekshibisi (baik live atau delayed) televisi melanjutkan proses komodifikasinya. Untuk itu biasanya media massa komersial akan mencari sponsor sebagai pengiklan untuk membiayai seluruh kegiatan produksi dan fee untuk televisi yang bersangkutan (Rangkuti: 2009). Hal 
itu masih belum cukup, simbol da'i atau da'iyahnya juga dikomoditaskan. Sehingga nampak di layar kaca merek apa kerudung yang sedang dipakai oleh sang da'iyah.

Audiens tahu persis bahwa Mamah Dedeh adalah da'iyah yang dikenal keras tanpa kompromi. Modal itulah yang nampaknya disukai oleh pemirsa Indosiar. Padahal bagi muslim yang ahli baca al-Qur'an, bacaan Mamah Dedeh dapat dikatakan biasa, bahkan cenderung kurang fasih dan belum layak diperdengarkan kepada khalayak umum, apalagi dalam kapasitasnya sebagai ulama.

Dalam hal hukum agama, dia tampil dengan begitu hebatnya hingga mampu menjawab semua persoalan yang diajukan si pencurhat. Bagi ahli hukum Islam, jawaban yang disampaikannya seringkali cenderung kurang pas, dia acapkali mengambil dalil secara serampangan, tanpa perangkat metodologis yang memadai. Padahal Ulama sekaliber Imam Malik saja tidak mampu menjawab mayoritas pertanyaan yang diajukan kepada beliau.

Lain halnya dengan Ustadz Nur Maulana, tampilannya yang modernis, memiliki bacaan al-Quran yang lebih baik dari pendahulunya, kocak, ditambah dengan hadirnya artis dan aktor yang sedang naik daun menjadikan acara ini menarik bagi pemirsa, khususnya ibu-ibu majlis taklim. Sejak tayang di TransTV di tahun 2011 program itu masih bertahan menghias layar kaca sampai sekarang, dan di tahun 2011 pula rating acara yang diasuhnya bertajuk Islam itu Indah dapat dibilang bagus. Program ini menempati peringkat 15 . Namun sikap berlebihan dengan sensasionalisasi gestur sang da'i, personalisasi oleh artis pendukung, dramatisasi dengan akting menangis membuat acara ini tampak lebih tidak serius daripada aplikasi ajaran agama itu sendiri. Modus acara ini jelas menyiratkan produk komodifikasi dalam konten.

Bahkan demi menggandakan keuntungan, TransTV tidak segansegan membuat program keagamaan ala spot tanpa menghadirkan ulama 
atau ahli agama. Seperti misalnya program khazanah. Acara ini hanya mengandalkan narator yang mungkin hanya tinggal membaca skrip yang sudah disiapkan tim kreatif. Tidak heran bila didapati si narator salah dalam membaca ayat atau hadis tertentu. Tidak jarang pula narator hanya cukup membaca terjemah dari ayat atau hadis yang dikutip demi menutupi ketidakmampuan mereka untuk membaca teks Arab. Tidak heran pula bila beberapa tema yang ditayangkan kerapkali mengundang polemik. Seperti ketika mereka mengharamkan shalawatan atau melagukan bacaan shalawat (www.sarkub.com).

Demikian halnya dengan saudara kembarnya, Trans7. Dalam program Cermin Kehidupan yang tayang di pagi hari, aktor dan artis pendukungnya didominasi oleh pendatang baru. Artis senior yang sudah jarang tampil di televisi dipasang untuk memancing audien angkatan lama. Semua itu dilakukan dengan satu motif bayaran murah untuk para artis pendukungnya.

Sementara dalam distribusi program dapat disaksikan terjadinya keseragaman dalam program yang ditayangkan. Program Mamah dan AA Beraksi yang disaksikan oleh penonton di beberapa daerah akan sama dengan yang penonton Jakarta saksikan. Artinya keseragaman ini murni untuk kepentingan ekonomi, bukan dari sudut pandang teknis semata.

Pada akhirnya isi simbol agama hanyalah sebuah benda dan jasa yang tak lebih berarti dari kertas berangka rupiah. Dalam komodifikasi isi, komodifikasi nampak terjadi dalam produksi, distribusi dan ekshibisi program di televisi komersial.

\section{Audiens sebagai Komoditas Televisi Komersial}

Menurut Smythe (dalam Mosco, 1996) media massa merupakan proses di mana perusahaan media memproduksi penonton dan mengantarkannya pada pengiklan. Sementara pengiklan membayar perusahaan media untuk bisa mengakses penonton yang bisa diantarkan menjadi 
iklan-iklan.

Dalam praktiknya seperti telah disinggung di muka bahwa tujuan akhir dari media komersial adalah rating. Rating atau tingkat ketertontonan televisi adalah jumlah penonton atau pesawat televisi yang memilih channel suatu stasiun televisi dengan hitungan per-seribu orang. Bila sebuah program berating 15 maka penonton atau pesawat televisi yang menyaksikan acara tersebut adalah 15.000 orang.

Rating menjadi penting sebab dapat mempengaruhijumlah dan harga iklan di televisi. Sebagi gambaran harga iklan di televisi komersial nasional berkisar antara 5-16 juta perslot (30 detik) tergantung dari rating acara, jam tayang, positioning, dan faktor lainnya (http://harga.web.id/). Sedangkan share atau tingkat persentase ketertontonan televisi adalah persentase orang atau pesawat televisi yang memilih untuk menonton program tertentu pada jam atau waktu tersebut. Misalnya jam 13.00 wib ada program berita A dengan share 20, program gosip B share 30 dan program sport dengan share 50. Artinya program berita A mendapat 20 persen penonton pada jam 13.00 wib, program gosip B mendapat bagian 30 persen penonton dan program sport $\mathrm{C}$ mendapat 50 persen penonton pada jam 13.00 wib.

Rating dapat diperoleh dengan alat yang disebut dengan peoplemeter. Peoplemeter adalah alat pengukur khalayak yang dengan seizin pemilik rumah, diletakkan di dekat pesawat televisi beserta handset-nya. Bahkan alat tersebut bisa mencatat dan mengetahui seorang tamu yang kebetulan ikut menonton televisi tuan rumah (Nurudin, 2008).

Stasiun televisi komersial tidak perlu repot-repot memasang sendiri alat itu di rumah-rumah penduduk. Mereka cukup mendapatkan data pemirsanya dari lembaga akuntan publik yang akuntabel. Sampai saat ini televisi komersial di Indonesia mengandalkan data dari perusahaan akuntan publik multinasional AGB Nielsen dengan cara membeli. Asumsi audiens sebagai komoditas nampak pada sisi konsumsi media dimana audiens dikonversi menjadi angka untuk dijual kepada pengiklan. 


\section{Rating Sebagai Komoditas Cybernetic: Komodifikasi Intrinsik Televisi Komersial}

Istilah cybernetic atau dibahasaIndonesiakan dengan sibernetika mengacu pada konsep teori mekanika tentang pengaturan diri secara otomatis (Rakhmat, 2011). Dalam bahasa yang lebih mudah dapat diartikan sebagai kontrol. Maksudnya rating secara otomamatis dapat mengontrol kebijakan penyiaran suatu program oleh sebuah stasiun televisi komersial.

Bila di muka telah disinggung bahwa rating adalah komoditas, maka Meehan (dalam Mosco, 1996) memiliki cara pandang berbeda. Baginya rating menjadi penting karena mewakili tingkat lanjut dalam proses komodifikasi di media. Dalam cara pandang ini sebuah stasiun komersial akan menjadikan rating sebagai parameter apakah suatu program seperti acara keagamaan dapat dilanjutkan atau tidak.

Dalam realitasnya program semacam Islam itu Indah milik TransTV atau Mamah dan AA beraksi milik Indosiar sampai saat ini masih tayang. Entah berapa kali proses komodifikasi isi, baik itu pesan dan simbol diproduksi dan direproduksi lagi. Kebijakan untuk memperpanjang program ini bagian dari komoditas instrinsik dari rating.

\section{Agama Sebagai Komoditas Cybernetic: Komodifikasi Ekstensif Televisi Komersial}

Idealnya, agama adalah institusi sakral lagi istimewa. Agama jelas tidak layak dikomersilkan. Komodifikasi adalah tindakan tidak etis yang dilakukan terhadap agama. Oleh karena itu bagi Karl Marx, komodifikasi adalah pembayaran tunai yang tidak berperasaan. Agama jelas lebih dari sekedar edukasi publik, informasi pemerintah, media, budaya, dan telekomunikasi yang jelas-jelas dibangun di luar area kontestasi kekuatan dan motif. 
Komodifikasi ekstensif memandang agama merupakan komoditas sempurna. Hampir semua format acara di televisi komersial tidak lepas dari simbol agama. Dakwah, sinetron, berita, iklan, kontes kecantikan bahkan jurnalisme ala gosip yang sejatinya tidak ada kelit-kelindan dengan agama juga ikut menampung isu dan simbol agama selama menguntungkan secara ekonomi.

Bagi kapitalis media, tentu tidak ada yang salah dengan apa yang mereka lakukan. Bagi mereka jasa dan produk adalah komoditas yang dapat dipertukarkan secara ekonomi. Dalih mereka adalah konsumen. Masyarakat dianggap sebagai konsumen tetap dari produk yang mereka siarkan dalam bentuk informasi dan hiburan. Sedang advertisers adalah pihak yang menengahi hubungan dikotomis antara media dengan audiensnya. Para pengiklan itu membutuhkan pembeli untuk produk yang mereka tawarkan. Dalam pandangan ekonomi kapitalis hubungan trikotomi media, pengiklan dan audiens adalah hubungan yang logis dan saling menguntungkan, lalu apa yang salah dari relasi ini? Kembali persoalan etis menjadi jawaban. Paling tidak hal ini dapat dilihat dari adanya relasi trikotomi yang tidak seimbang. Relasi trikotomi itu masih menempatkan media dan pengiklan di puncuk struktur piramida terbalik. Sementara audiens sendiri di bagian bawah piramida. Artinya meskipun pemirsa mendapatkan hiburan dan informasi, namun tidak semua hiburan dan informasi seperti yang mereka inginkan. Sebaliknya media dan para pengiklan mendapatkan apa yang mereka inginkan. Terlebih bila dikaitkan dengan agama yang dianggap sebagai sumber nilai dan etika dalam kehidupan manusia.

\section{Islam Sebagai Komoditas Televisi Komersial.}

Indonesia merupakan negara dengan pemeluk Islam terbesar di dunia. Lebih dari 70\% penduduknya memilih Islam sebagai jalan hidup. Meski tidak diketahui dengan pasti dari jumlah yang besar itu besaran dari 
muslim yang taat. Meski pula belum didapati data korelasi antara muslim yang taat dengan kebiasaan bermedia berkait konten keislaman. Namun setidaknya ada celah untuk menguliknya melalui preferensi pemirsa.

Koentjaraningrat telah lama menyebut agama sebagai salah satu dari unsur kebudayaan. Meski banyak pihak menganggap agama terlalu sakral untuk didekati dengan pendekatan tertentu yang cenderung bias Barat, seperti halnya pendekatan antropologi, disiplin ilmu yang begitu dikuasai olehnya. Namun paling tidak pendapat ini ada benarnya bila mengaca pada konsep ijtihad dalam hukum Islam. Meski memiliki metodologi dan mengacu kepada dalil naqli hasil ijtihad juga merupakan hasil olah pikir manusia.

Islam hampir pasti dapat disebut sebagai budaya bagi masyarakat di Indonesia. Jumlah pemeluk yang besar menjadi bukti nyata adanya pengaruh sosiokultural Islam pada masyarakatnya. Bahkan sila pertama dari Pancasila bisa disebut adopsi dari sistem ketuhanan dalam Islam. Kedekatan Islam sebagai budaya terefleksikan melalui program-program dan isu keislaman lainnya di televisi komersial. Artinya secara psikologis terdapat kedekatan budaya antara pemirsa muslim di Indonesia dengan siaran keislaman di televisi.

Pemirsa televisi menginginkan tontonan yang sesuai budaya mereka sendiri. Sebuah tontonan bagi mereka akan menjadi tuntunan dalam menjalani hidup, bukan sekedar hiburan. Alasan inilah yang selalu dilantunkan media untuk membenarkan tindakannya. Islam dijadikan komoditas oleh televisi komersial antara lain karena alasan preferensi pemirsa.

Asumsi demikian itu diamini oleh La Pastina dan Staubhbaar (2005, dalam Moran dan Chung) dengan teori cultural proximity theory (teori kedekatan budaya). Bahkan secara khusus La Pastina dan Staubhbaar berpendapat bahwa pemirsa televisi lebih suka menonton program yang mereka anggap sebagai budaya yang relevan, bahkan ketika penyiar 
adalah jaringan atau orang asing.

Di dalam program Hafidz Indonesia di RCTI, Syeikh Ali Jabir; juri dari Madinah, yang meskipun tidak seetnis dengan pemirsapun dipilih menjadi pengadil, karena dianggap memiliki kedekatan budaya dengan pusat diturunkannya Islam. Padahal banyak hafidz lokal yang secara kualitas tidak kalah atau bahkan lebih hebat darinya. Begitu pula siaran langsung tarawih dari Masjidil Haram, bagi sebagian orang tentu akan menjadi lebih menarik disimak dibanding program wayang kulit yang merupakan budaya lokal dan disiarkan oleh televisi lokal. Tidak berlebihan pula bila sinetron seri yang mengusung simbol agama seperti Tukang Bubur Naik Haji (TBNH) selalu menempati rating tertinggi. Berdasarkan data Rating Televisi Indonesia pada tanggal 5 Mei 2015 TBNH menempati rating tertinggi dengan 4,6 dan share 17,8\%, yang lebih membanggakan program yang digeser posisinya adalah Jodha Akbar yang pada tanggal yang sama turun di peringkat keempat.

\section{Simpulan}

Islam dan media adalah bagian dari sistem sosial Indonesia. Realitanya televisi komersial di Indonesia tidak mengindahkan persoalan etika. Hampir semua konten televisi komersial dikonversi menjadi "agama" dengan berbagai ragam bentuk komoditas. Komodifikasi terjadi di hampir seluruh level. Mulai dari level produksi, distribusi, ekshibisi, hingga konsumsi. Hingga tidak didapati ruang ideal bagi agama di televisi komersial.

Desain agama seharusnya sepi dari hingar-bingar area kontestasi media. Audiens sebagai pemilik sah frekuensi yang digunakan oleh televisi komersial tidak mendapatkan hak pendidikan, khususnya di bidang agama, namun apa lacur media di Indonesia hidup di dalam sistem yang market based power. Media harus belajar untuk mulai menjadikan audiens sebagai mitra, bukan sebagai target market saja. 
INJECT: Interdisciplinary Journal of Communication, Vol.1, No.1, Juni 2016: h. 25-42

\section{Daftar Pustaka}

Cangara, Hafied. 2007. Pengantar Ilmu Komunikasi. Jakarta: RajaGrafindo Persada

Mc Quail, Dennis. 2002. Media Policy: convergence, concentration and commerce. London: Sage Publications . 2005. Mass Communication Theory. London: Sage Publications . 1994. Teori Komunikasi Massa (terjemahan). Jakarta: Erlangga

Mosco, Vincent. 1996. The Political Economi Of Communication: Rethingking and Renewal. London: Sage Publications

Onong, Uchyana Effendi. 2003. Ilmu Komunikasi Teori dan Praktek. Bandung: Remaja Rosda Karya

Rakhmat, Jalaluddin 2011. Psikologi Komunikasi. Bandung: Remaja Rosda Karya

Rangkuti, Freddy . 2009. Strategi Promosi yang Kreatif dan Analisis Kasus Integrated Marketing. Jakarta: Gramedia Pustaka Utama

Samovar, A. Larry dkk. 2010. Komunikasi Lintas Budaya Edisi Tujuh. Jakarta: Salemba Humanika

Severin, J. Werner. Jr, Tankard, W. James. 2009. Teori komunikasi: Sejarah, Metode, dan Terapan di Dalam Media Massa Edisi Lima. Jakarta: Prenada Media.

\section{Sumber Jurnal dan Internet:}

Moran, Kristin C. dan Leeva C. Chung. Global or Local Identity? A theoretical analysis of the role of Viacom on identity among children in an international context. Global Media Journal: Volume 7, Issue 12 | Spring 2008

http://digilib.esaunggul.ac.id/proses-produksi-acara-happy-songdiindosiar-4782.html

https://id-id.facebook.com/RatingAcaraTelevisiIndonesia http://nouriesblog.blogspot.com/2012_12_30_archive.html http://sarkub.com).

http://harga.web.id/ 